\title{
Submicroscopic Structure of Equine Articular Cartilage
}

\author{
D. HORKÝ ${ }^{1}$, F. TICHÝ 2 \\ ${ }^{1}$ Department of Histology and Embryology, Faculty of Medicine, Masaryk University, Brno \\ ${ }^{2}$ Department of Anatomy, Histology and Embryology, \\ University of Veterinary and Pharmaceutical Sciences, Brno \\ Received September 10, 2001 \\ Accepted June 19, 2002
}

Abstract

Horký D., F. Tichý: Submicroscopic Structure of Equine Articular Cartilage. Acta Vet. Brno 2002, 71: 151-157.

The articular cartilage of knee and tarsal joints was studied by transmission electron microscopy in two 2- and two 8-year-old male horses. Samples were collected from regions subjected to mechanical loading.

The superficial layer in both age categories was characterized by spindle-shaped chondrocytes distributed throughout the whole layer and lying parallel to the surface. The 8-year-old horses showed signs of arthrosis, such as uncovering of cells which, consequently, came into contact with the joint cavity, disappearance of the chondrosynovial membrane, presence of fissures in the intercellular matrix and, occasionally, cell necrosis. These changes were associated with a thickening of collagen fibrils.

The middle layer was characterized by oval chondrocytes, surrounded by a narrow pericellular matrix, located in the extracellular matrix and by rounded cells sending out short projections into the intercellular matrix. The cytoplasm of both cell types contained cell organelles, glycogen and bundles of intermediate filaments as well as crystals, probably of protein origin, which assumed rhombic, rhomboid or trapezoidal shapes.

The deep layer consisted of isogenetic groups of chondrocytes aligned in columns perpendicular to the cartilage surface. The cells were localized in lacunae with a narrow pericellular space. Their numerous projections extended into the intercellular matrix. The cytoplasm showed distinct bundles of intermediate filaments encircling the nucleus. In the vicinity of the tide mark, fibrocytes were observed. The extracellular matrix in this layer was composed of thick bundles of collagen fibrils.

Horse, articular cartilage, ultrastructure, arthrosis

The role of articular cartilage in joint function is largely mechanical. If the joint is to function properly, this tissue has to meet two principal requirements: (i) it must resist mechanical forces produced in different regions of the joint and (ii) facilitate sliding and lubrication of the contact surfaces. Cartilage is adapted to resist forces by the structure of its extracellular matrix consisting of two components, i.e., ground amorphous substance and collagen fibrils (Bloebaum and Wilson 1980; Clark 1991). Chondrocytes are involved in the mechanics of joint movement to a minimal degree but have a key role in the synthesis of intercellular matrix that is responsible for mechanical properties of the cartilage (Maroudas 1973; Buckwalter et al. 1989 and others). The superficial cartilage layer has the main role in facilitating the sliding and lubrication of contact surfaces (W olf 1975; Giles 1992; Horký 1993ab, 1994ab; Nixon 1993).

Both the structure and ultrastructure of articular cartilage have been studied in almost all mammals and some birds (Jubb et al. 1985; Bozděch et al. 1990; Horký 1994ab and others). Although, in horses, the structure of articular cartilage has been described, most of the reports were concerned with either pathological processes in joints (Riddle 1970), surgical procedures carried out on joints (McIlwraith 1990; McIlwraith and Martin

Address for correspondence:

Prof. MUDr. D. Horký, DrSc.

Dept. of Histology and Embryology

Dept. of Histology and Embryology
Faculty of Medicine, Masaryk University

Phone: +420542126213

Fax: + 420541562217

66243 Brno

http://www.vfu cz/acta-vet/actavet htm 
1984; Sullins et al. 1985) or alterations in articular cartilage after therapeutic or experimental administration of different agents (McIlwraith and Van Sickle 1981; Shoemaker et al. 1992). Only very few data concerning the normal structure of articular cartilage at various ages was found. Therefore, this study was design with the objective to provide more consistent information on the adult articular cartilage in horses of different ages.

\section{Materials and Methods}

Articular cartilage was collected from the knee and tarsal joints of four male horses, aged 2 and 8 years, to be examined by transmission electron microscopy. Samples were taken from regions subjected to mechanical loading forces. Strips, $1 \times 1 \times 3 \mathrm{~mm}$ in size, were cut out from the samples and immediately fixed in a $400 \mathrm{mmol} / \mathrm{l}$ solution of glutaraldehyde in $0.1 \mathrm{M}$ phosphate buffer at $\mathrm{pH}$ 7.4. The tissue was subsequently decalcified using two solutions of $0.1 \mathrm{M}$ EDTA containing $400 \mathrm{mmol} / \mathrm{l}$ glutaraldehyde at $\mathrm{pH} \mathrm{7.2,} \mathrm{for} 60 \mathrm{~min}$ each, then allowed to stand in the decalcification solution overnight, and eventually rinsed for $30 \mathrm{~min}$ in each of the four baths containing $0.1 \mathrm{M}$ phosphate buffer at $\mathrm{pH}$ 7.4. Fixation was carried out in two baths of $40 \mathrm{mmol} / 1 \mathrm{OsO}_{4}$ solution in phosphate buffer at $\mathrm{pH}$ 7.4.

Dehydration, immersion and embedding in Durcupan ACM followed the standard procedure. For light microscopy, semi-thin sections were cut and stained with methylene blue and Azur II. Ultrathin sections were made on an LKB Nova ultramicrotome and stained with lead citrate or with uranyl acetate and lead citrate. The sections were viewed and photographed in a Tesla BS 500 electron microscope.

\section{Results}

In the cartilage samples studied, three distinct layers (superficial, middle and deep), were distinguished.

Submicroscopic structure of the superficial layer

In young adult animals, spindle-shaped chondrocytes, lying parallel to the surface, comprised one or two layers (Plate I, Fig. 1). The chondrocytes were up to $15 \mu \mathrm{m}$ long but not more than $2 \mu \mathrm{m}$ thick. The nucleus was elongated and measured about $4 \mu \mathrm{m}$. Chromatin was arranged to form several large karyosomes adjacent to the nuclear envelope. The cytoplasm, generally in small amounts, was accumulated at both cell poles. It contained small mitochondria, cisterns of the granular endoplasmic reticulum (GER) and a small Golgi apparatus. Intermediate filaments were not observed. The cytoplasmic membrane, forming numerous short projections, extended into the surrounding intercellular matrix. Chondrocytes situated close to the surface were seen only occasionally and, in these instances, their projections extended under the chondrosynovial membrane (Plate I, Fig. 2).

The distinction of the extracellular matrix into pericellular and intercellular matrix, was not very clear. In the majority of cases, the pericellular matrix was narrow and the intercellular matrix extended up to the cell membrane (Fig. 1). Small regions close to the cell membrane on the side away from the surface were the only areas containing aperiodic filaments. The intercellular matrix consisted of collagen fibres with a typical periodicity (Fig. 2) situated parallel to the surface. On the surface of the articular cartilage there was a chondrosynovial membrane composed of aperiodic fibrils (Fig. 2) accumulated close to the surface and in the vicinity of chondrocyte projections. They formed bundles following an oblique or parallel course in relation to the surface (Fig. 2).

In regions showing signs of arthrosis, the surface layer had a different appearance. Chondrocytes were found in a single layer about $6 \mu \mathrm{m}$ under the surface and some even in direct contact with the joint cavity (Plate II, Figs 3 and 4). They were spindle-shaped or rounded (Fig. 4). Those located close to the articular surface showed signs of developing necrosis. The nucleus was hyperchromatic with a blurred chromatin structure; the cytoplasmic membrane was disintegrated, thus allowing the release of cell organelles, such as mitochondria, outside the cell (Fig. 4).

However, the most prominent changes took place in the structure of intercellular matrix. The chondrosynovial membrane disappeared (Fig. 3) and the collagen fibres situated under 
the surface layer of cells no longer maintained their periodicity (Figs 3 and 4). In the amorphous ground substance there were empty spaces occasionally containing disintegrated organelles (Fig. 4). The intercellular matrix, located under this region showing arthrotic changes, had the usual structure.

Submicroscopic structure of the middle layer

Chondrocytes in the middle layer were seen as individual cells distributed throughout the extracellular matrix (Plate III, Figs 5 and 6) and, only in deep parts of this layer, they were arranged in pairs enclosed in a lacuna. They were oval or spherical in shape (Figs 5 and 6). The shape of the nucleus was similar to that of the cell. Chromatin was aggregated into several large karyosomes located at the nuclear envelope. The zonula nucleum limitans had a typical appearance. A nucleolus of the reticular type was always present (Fig. 6). The cytoplasm showed sparse, electron-dense mitochondria, frequent, dilated GER cisterns and a well-developed Golgi apparatus with smooth, dilated cisterns and vesicles (Figs 5 and 6). Glycogen deposits (Fig. 6) and bundles of intermediate filaments partially encircling the nucleus (Figs 5 and 6) were conspicuous cytoplasmic inclusions. Lipid droplets were not observed. In addition, crystalline inclusions either surrounded by GER cisterns (Fig. 5) or located in the region occupied by intermediate filaments (Fig. 6) were observed.

The cell membrane produced short projections extending into the intercellular matrix. The pericellular matrix was incompletely developed and, therefore, chondrocytes were not located in the usual lacunae (Figs 5 and 6). Consequently, their cell membranes were in immediate contact with the intercellular matrix. Collagen fibrils with a typical periodicity were interwoven in a thick network (Fig. 6). Some of the fibrils were twice as thick as the others, and, in cross sections, they had an appearance of dark, rounded bodies situated among thinner fibrils (Fig. 6).

\section{Submicroscopic structure of the deep layer}

Chondrocytes in this layer were most often found in groups of two or three enclosed in lacunae situated perpendicular to the cartilage surface (Plate IV, Fig.7). They were crescentshaped and, in the lacuna, they were separated by a septum formed by pericellular matrix. They were up to $4-8 \mu \mathrm{m}$ in size. The shape of the nucleus was similar to that of the cell and the nuclear envelope had, in some regions, deep invaginations (Fig. 7). Chromatin was organized in several large karyosomes situated at the nuclear envelope and was also present, as perinucleolar chromatin, close to the nucleolus that was reticular or ring-like in shape (Fig. 7). In contrast to the chondrocytes in the surface- and middle layers, glycogen granules were diffusely distributed in the cytoplasm among large bundles of intermediate filaments surrounding the nucleus; the cytoplasm also contained lysosomes. The cell membrane produced numerous short projections that extended only into the pericellular matrix.

In the deep part of this layer, another cell type was seen in addition to chondrocytes. The appearance, cell shape and the number and location of projections indicated that these cells were typical fibroblasts. Each of these spindle-shaped cells, containing the nucleus and most of the cytoplasm, formed several long projections involving organelles. The projections were located among the large bundles of collagen fibrils that were in close contact with the cell membrane (Fig. 8).

The extracellular matrix was differentiated into the pericellular and intercellular matrix in the regions where isogenetic groups of chondrocytes were present. The perinuclear matrix, when present, included aperiodic fibrils and thin collagen fibrils (Fig. 7). Its width ranged between 1 and $2 \mu \mathrm{m}$. The intercellular matrix did not differ in either structure or collagen fibril location from the matrix in the middle layer, except for the presence of a larger number of dark granules among the fibrils (Fig. 7). 


\section{Discussion}

The ground amorphous substance with its fibrillar component, i.e., the extracellular matrix, plays an important role in the function of articular cartilage in synovial joints. In the surface layer, it is responsible for sliding and lubrication and, in the middle and deep layers, it facilitates resistance to mechanical forces and their distribution onto the subchondral bone. The cellular component of articular cartilage is involved in cartilage synthesis, a fact reported many years ago by Sheldon and Kimbal (1962) and Freeman and Kepson (1973). The equine articular cartilage includes three layers, a finding also made in other mammals (Palfrey and Davies 1966; Horký 1991ab, 1994ab and others). The observations reported here are in agreement with the results obtained by Modl et al. (1991) on the basis of magnetic resonance examination and also with our previous findings made in articular cartilage of several mammalian species studied by transmission electron microscopy (Horký 1980; Ghadially 1983; Bozděch et al. 1990; Horký 1994 ab).

Our observations on the chondrosynovial membrane in the horse as well as in other mammals that have been studied previously, are also in accordance with the findings of Wolf (1975), Stockwell and Meachim (1979) and other authors. Similar results were also reported by Giles (1992) and Kamalanathan and Broom (1993). All these findings give support to our view which disagrees with those of McCutchen (1966) and Maroudas (1973) who claim that the chondrosynovial membrane is produced by the ultrafiltration of synovial fluid through the surface cartilage layer. In our opinion, based on repeated observations (see above cited references), this structure is synthesized by the bundles of aperiodic filaments, located either on or immediately below the surface of articular cartilage, without their polymerization in typical collagen fibrils. This process gives rise to a membrane, which is very thick in the prenatal period and grows thinner with increasing age, capable of ensuring the gliding of surfaces that, often under extreme pressure, rub against each other (Cappuis et al. 1983; Swann et al. 1984; Hills 1990). The joint surfaces are lubricated by synovial fluid, a product of synovialocytes, in which the most effective component is lubricin. In an intact articular cartilage, synovial fluid is able to reduce the friction coefficient to 0.01 .

The chondrosynovial membrane grows thinner with ageing and the number of collagen fibrils in the intercellular matrix increases. These fibrils are responsible for cartilage elasticity, while proteoglycans in the amorphous ground substance are responsible for resistance to mechanical forces. Our findings of fibril arrangement in this study corresponded well with the observations by Bloebaum and Wilson (1980) and Clark (1990) as well as with our results from previous investigations carried out in several mammalian species during prenatal and postnatal periods (Horký 1986, 1987, 1989, $1991 \mathrm{ab}, 1993 \mathrm{ab}, 1994 \mathrm{ab})$. The superficial layer has been found to contain bundles of aperiodic fibrils varying in width and length. In the horse, the bundles were not as large as, for instance, in the goat (Horký 1994 b), which was obviously due to bundle loosening. Other authors have also paid attention to this structure since it plays an important role in the synthesis of the fibrillar component of articular cartilage (Broom 1986; Clark 1990; Jeffery et al. 1991; Hedlung et al. 1993).

The surface layer of articular cartilage in some regions had a different appearance, showing signs typical of arthrosis (Horký 1980; Ghadially 1983; Bozděch et al. 1990). This was not an unusual finding because Wiltberger and Lust (1975) and Grondalen (1974abcd) have reported this feature in dogs and pigs under various conditions and after experimental treatment. Similar changes were described by Bibb and Robinson (1993) in primates undergoing repair after artificial defects of articular cartilage. 
The structure of the middle layer of articular cartilage in horses was similar to that described in other mammalian species (Gilmore a Palfrey 1988; Horký 1989, 1991ab, $1994 \mathrm{ab}$ ). However, there were some differences such as the accumulation of larger amounts of glycogen in some chondrocytes and the presence of crystals, possibly proteinaceous in nature, whose origin and structure were not analysed. Also the arrangement of the fibrillar component of the intercellular matrix was different. The pericellular matrix was poorly developed so that collagen fibrils came into direct contact with the cell membrane of chondrocytes; this has also been observed in the feline articular cartilage (Horký and Tichý 1995). Collagen fibrils did not encircle chondrocytes as in cattle (Horký 1993) or humans (Horký 1993).

The deep layer of articular cartilage showed a structure similar to this layer of articular cartilage in other mammals (Hedlung et al. 1993; Horký 1991c, 1993a, 1994b).

\section{Submikroskopická struktura kloubní chrupavky koně}

Byla studována kloubní chrupavka kolenního a hlezenního kloubu 4 jedinců samčího pohlaví stáří 2 a 8 roků. Vzorky chrupavky byly odebrány pro transmisní elektronovou mikroskopii ze zátěžové oblasti a chrupavka byla zpracována obvyklým způsobem.

Bylo zjištěno, že v povrchové vrstvě chrupavky obou věkových kategorii jsou chondrocyty vřetenovitého tvaru uloženy $\mathrm{v}$ různé hloubce paralelně s povrchem. U koně stáří 8 rokủ se objevují známky artrózy, např. demaskování buněk, které se dostávají do kontaktu s kloubní dutinou, vymizení chondrosynoviální membrány, štěrbiny v mezibuněčné hmotě a ojediněle nekróza buněk. V jejich blízkosti dochází ke zhrubnutí kolagenních vláken.

Ve střední vrstvě se vyskytují chondrocyty jednak oválného tvaru, uložené v mezibuněčné hmotě, s úzkou pericelulární matrix, jednak buňky okrouhlé s krátkými výběžky, zasahujícími do intercelulární matrix. V obou typech buněk jsou v jejich cytoplazmě kromě buněčných organel, gykogenu a svazků intermediárních filament uloženy krystaly pravděpodobně bílkovinného původu podoby kosočtverce, kosodélníka nebo lichoběžníka.

Hluboká vrstva je tvořena isogenetickými skupinami chondrocytů, které jsou uspořádány do řad kolmo k povrchu chrupavky. Buňky jsou uloženy v lakunách s úzkým pericelulárním prostorem. Četné výběžky zasahují až do intercelulární matrix. V cytoplazmě jsou nápadné svazky intermediárních filament, které obkružují jádro. V sousedství s tide mark se vyskytují i fibrocyty. Mezibuněčná hmota je tvořena v této oblasti mohutnými svazky kolagenních fibril.

\section{References}

BIBB, CA, ROBINSON, PD 1993: Histologic study of articular cartilage repair in the marmoset condyle. J Oral Maxillofac Surg 51: 1088-1095

BLOEBAUM, RD, WILSON, AS 1980: The morphology of the surface of articular cartilage in adult rats. J Anat 131: $333-346$

BOZDĚCH, Z, HORKÝ, D, JANEČEK, M 1990: Chrupavka a synoviální tkáň lidského kloubu. Acta fak med. Univ Masaryk Brunensis 1-150

BROOM, ND 1986: The collagenous architecture of articular cartilage-a synthesis of ultrastructure and mechanical function. J Rheumatol 13: 142-152

BUCKWALTER, JA, SMITH, KC, KAZARIEN, LE, ROSENBERG, LC, UNGAR R 1989: Articular cartilage and intervertebral disc proteoglycans differ in structure:an electron microscopic study. J Orthop Res 7/1: 146151

CLARK, JM 1990: The organization of collagen fibrils in the superficial zones of articular cartilage. J Anat 171: $117-130$

CLARK, JM 1991: Variation of collagen fiber alignment in a joint surface: a scanning electron microscope study of the tibial plateau in dog, rabbit and man. J Orthop Res 9: 246-257

FREEMAN, MAR, KEMPSON, GE 1973: Load carriage. Adult articular cartilage. M.A.R. Freeman, Alden Press, Oxford, Great Britain, pp. 228-246

GHADIALLY, FN 1983: Fine structure of synovial joints. Butterworths, London, pp. 42-80 
GILES, LGF 1992: The surface lamina of the articular cartilage of human zygoapophyseal joint. Anat Rec 233: $350-356$

GILMORE, RSTC, PALFREY, AJ 1988: Chondrocyte distribution in the articular cartilage of human femoral condyles. J Anat 157: 23-31

GRONDALEN, T 1974a: Osteochondrosis and arthrosis in pigs. I. Incidence in animals up to $120 \mathrm{~kg}$ live weight. Acta Vet Scand 15: 1-25

GRONDALEN, T 1974b: Osteochondrosis and arthrosis in pigs. II. Incidence in breeding animals. Acta Vet Scand. 15: $26-42$

GRONDALEN, T 1974c: Osteochondrosis and arthrosis in pigs. III. A comparison of the incidence in young animals of the Norwegian Landrace and Yorkshire breeds. Acta Vet Scand 15: 43-52

GRONDALEN, T 1974d: Osteochondrosis and arthrosis in pigs. VI. Relationship to feed level and calcium, phosphorus and protein levels in the ration. Acta Vet Scand 15: 147-169

GRONDALEN, T 1974d: Osteochondrosis and arthrosis in pigs. VII. Relationship to joint shape and exterior conformation. Acta Vet Scand 15 (Suppl. 46): 1-32

HEDLUNG, H, MENGARELLI-WIDHOLM, S, REINHOLT, FP, SVENSSON, O 1993: Stereologic studies on collagen in bovine articular cartilage. APMIS, DNK 101: 133-140

HILLS, BA 1990: Oligolamellar nature of the articular surface. J Rheumatol 17: 340-356

HORKÝ, D 1980: Submicroscopic structure of the human joint cartilage. Acta Vet Brno 49: 145-176

HORKY, D 1987: Submicroscopic structure of bovine articular cartilage in in prenatal and early postnatal period.

Acta Vet Brno 56: 3-18

HORKÝ, D 1989: The ultrastructure of articular cartilage in the prenatal pig. Acta Vet Brno 58: 143-174

HORKÝ, D 1991a: Submicroscopic structure of articular cartilage in human embrya six to eleven weeks old. Acta Vet Brno 60: 15-30

HORKÝ, D 1991b: Submicroscopic structure of human articular cartilage in the period between 19 to 38 weeks after fertilization. Acta Vet. Brno 60: 111-126

HORKÝ, D 1991c: The submicroscopic structure of articular cartilage in swine in the early postnatal period. Acta Vet Brno 60: 323-334

HORKÝ, D 1993a: The submicroscopic structure of articular cartilage in the adult pig. Acta Vet Brno 62: 9-18

HORKY, D 1993b: The ultrastructure of articular cartilage in the prenatal domestic cat. Acta Vet Brno 62: 115120

HORKÝ, D 1994a: Feline articular cartilage in the prenatal and early postnatal periods. A scanning electron microscopic study. Acta Vet Brno 63: 33-39

HORKÝ, D 1994b: The submicroscopic structure of caprine articular cartilage in ontogeny. Acta Vet Brno 63: 4148

HORKÝ, D, TICHY, F 1995: Ultrastructure of feline articular cartilage in the postnatal period. Acta Vet Brno 64: 63-70

CHAPPUIS, J, SHERMAN, IA, NEUMANN, AW 1983: Surface tension of animal cartilage as it relates to function in joints. Ann Biomed Eng 11: 435-451

JEFFERY, AK, BLUNN, GW, ARCHER, CW, BENTLEY, G 1991: Three-dimnsional collagen architecture in bovine articular cartilage. J Bone Jt Surg B 73: 795-801

JUBB, KVF, KENNEDY, PC, PALMER, N 1985: Bones and Joints. In: Jubb KVF, Kennedy PC,Palmer N. (Eds.) Pathology of domestic animals, 3rd ed., Academic Press, 1: 2-122

KAMALANATHAN, S, BROOM, ND 1993: The biomechanical ambiguity of the articular surface. J Anat 183: 567-578

MAROUDAS, A 1973: Physico-chemical properties of articular cartilage. In: Adult articular cartilage. Ed.: MAR Freeman, Alden Press, Oxford, Great Britain, pp. 131-170

McILWRAITH, CW 1990: Diagnostic and surgical arthroscopy in the horse. Philadelphia: Lea and Febiger, pp. $15-25$

McILWRAITH, CW, Van SICKLE, DC 1981: Experimentally induced arthritis of the equine carpus:histologic and histochemicals changes in the articular cartilage. Am J Vet Res 42: 209-217

McILWRAITH, CW, MARTIN, GS 1984: Diagnostic and surgical arthroscopy of the carpal joint. In: McIlwraith C.W., ed.: Diagnostic and surgical arthroscopy in the horse. 1st.ed. Bonner Springs, Kan: Veterinary Publishing Co. $25-60$

McCUTCHEN, CW 1966: Boundary lubrication by synovial fluid: demonstration and possible osmotic explanation. Fed Proc 25: 1061

MODL, JM, SERHER, LA, HAUGHTON, VM, KNEELAND, JB 1991: Articular cartilage: Correlation of histologic zones with signal intensity at $\mathrm{mr}$ imaging. Radiology 181: 853-855

NIXON, AJ 1993: Structure and function of the surface of articular cartilage. Eq Vet Educ 3: 72-75

PALFREY, AJ, DAVIES, DV 1966: The fine structure of chondrocytes. Amer J Anat 100: 213-228

RIDDLE,WE 1970: Healing of articular cartilage in the horse. J Am Vet Med Assoc 157: 1471-1479

SHOEMAKER, RS, BERTONE, AL, MARTIN, GS, McILWRAITH, CW, ROBERTS, ED, PECHMAN R, KEARNEY, MT 1992: Effect of intraarticular administration of methyl-prednisolone acetate on normal articular cartilage and on healing in experimentally induced osteochondral defects in horses. Am J Vet Res 53: 1446-1453 
STOCKWELL, RA, MEACHIM, G 1979: The chondrocytes. In: Adult articular cartilage. 2nd edition. Ed.: M.A.R. Freeman, London, Pittman Medical 1979

SULLINS, KE, McILWRAITH, CW, POWERS, BE 1985: Evaluation of periosteal grafts in articular cartilage repair in horses. Vet Surg 14: 66-67

SWANN, DA, SILVER, FH, SLAYTER, HS 1985: The molecular structure and lubricating activity of lubricin isolated from bovine and human synovial fluids. Biochem J 225: 195-201

WILTBERGER, H, LUST, G 1975: Ultrastructure of canine articular cartilage: comparison of normal and degenerative (osteoarthritic) hip joints. Am J Vet Res 36: 72

WOLF, J 1975: Function of chondral membrane on surface of articular cartilage from point of view of its mechanical resistance. Folia Morphol (Prague) 23: 77-87 
Plate I

Horký D., Tichý F.: Submicroscopic... pp. 151-157

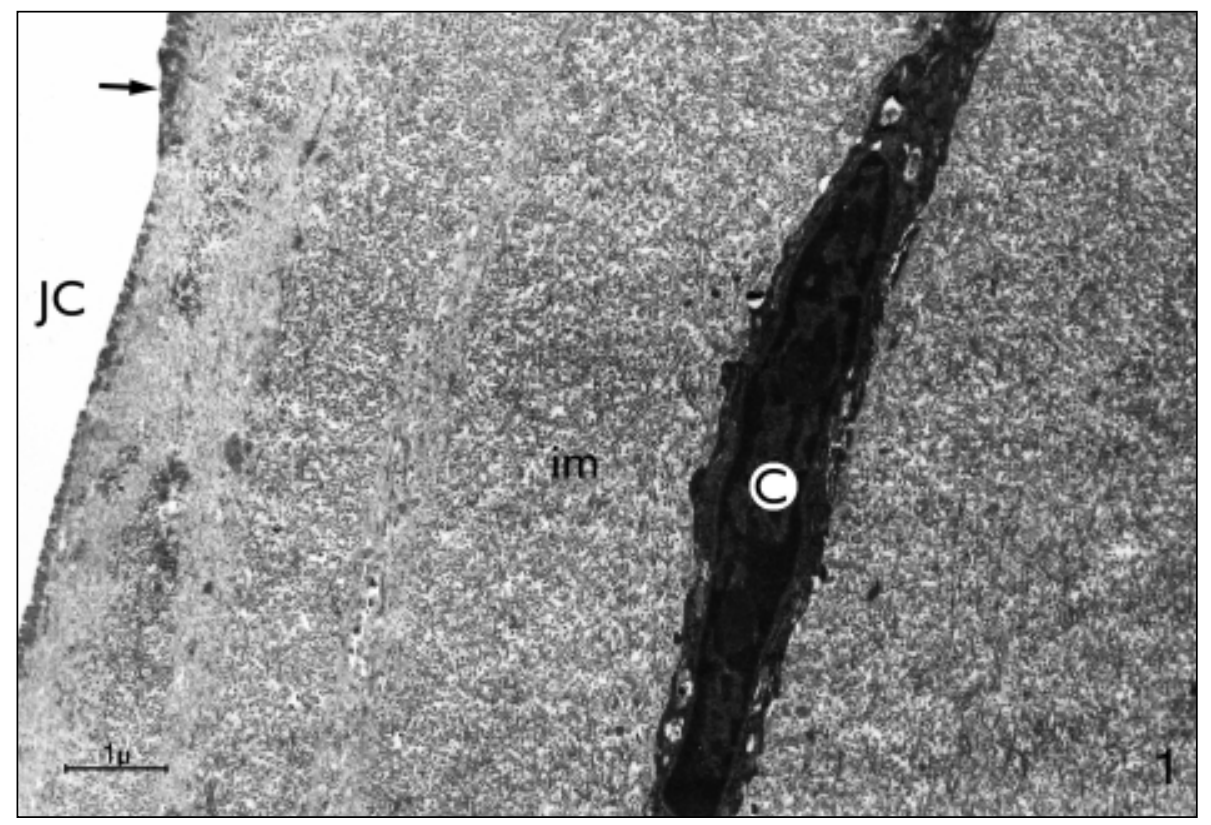

Fig. 1. Superficial layer of articular cartilage. Chondrocytes (C), intercellular matrix (im), chondrosynovial

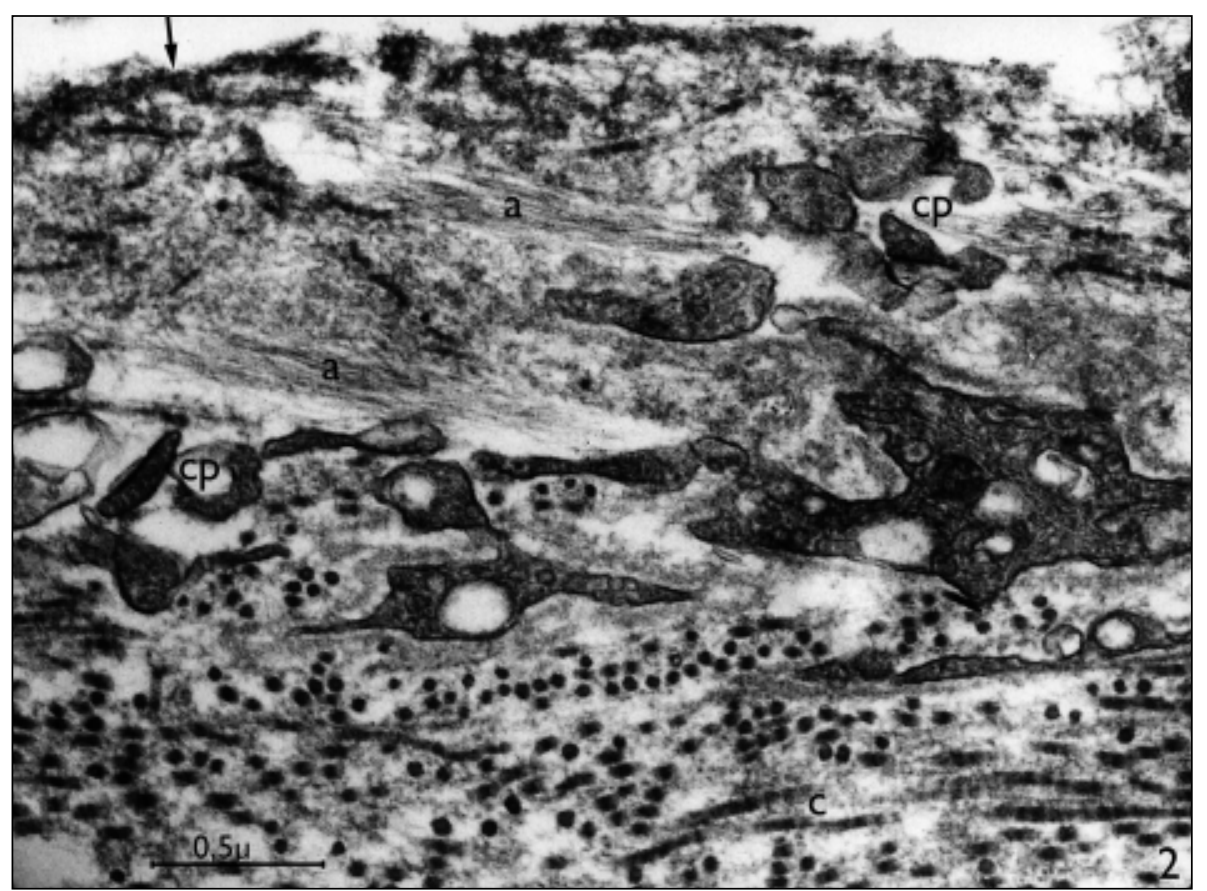

Fig. 2. Projections of chondrocytes in the superficial layer (cp), bundles of aperiodic fibrils (a) chondrosynovial membrane $(\rightarrow)$, collagen fibrils $($ c). Magnification $\times 40000$. 
Plate II

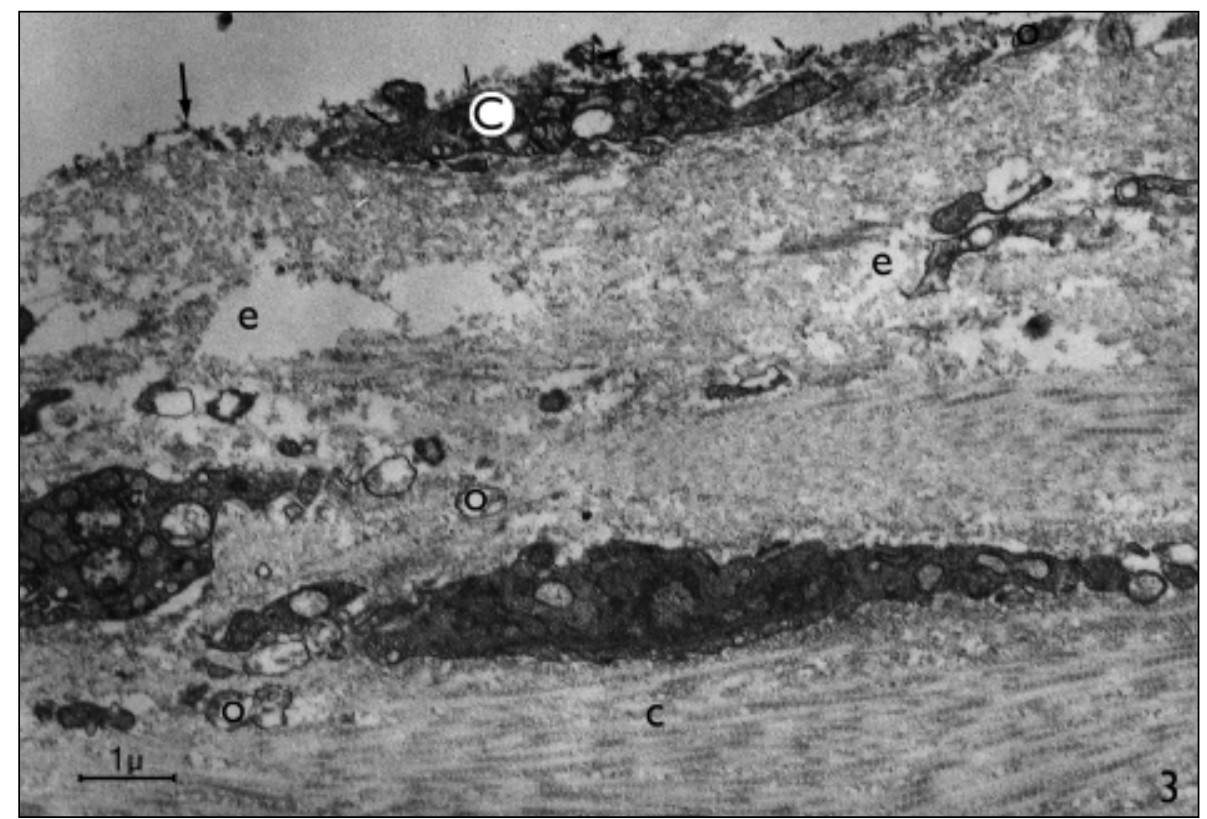

Fig. 3. A chondrocyte on the surface of articular cartilage (C). Bundles of thickened collagen fibrils with indistinct periodicity (c), cell organelles from disintegrated cells (o), damaged chondrosynovial membrane $(\rightarrow)$. Electron-transparent areas in the intercellular matrix (e). Magnification $\times 12000$.

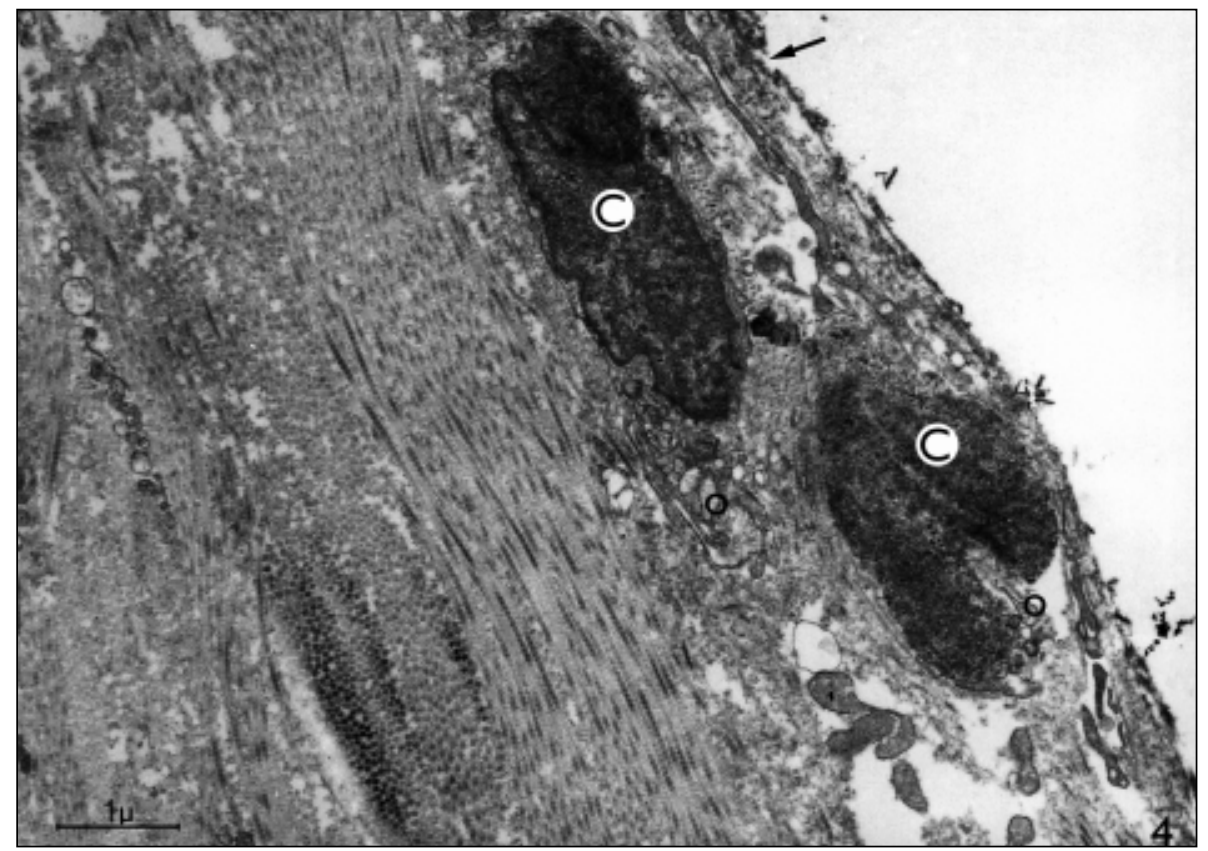

Fig. 4. Necrotic chondrocytes in the superficial layer (C), impaired organelles released from disintegrated cells (o), damaged chondrosynovial membrane $(\rightarrow)$. Magnification $\times 16000$. 
Plate III

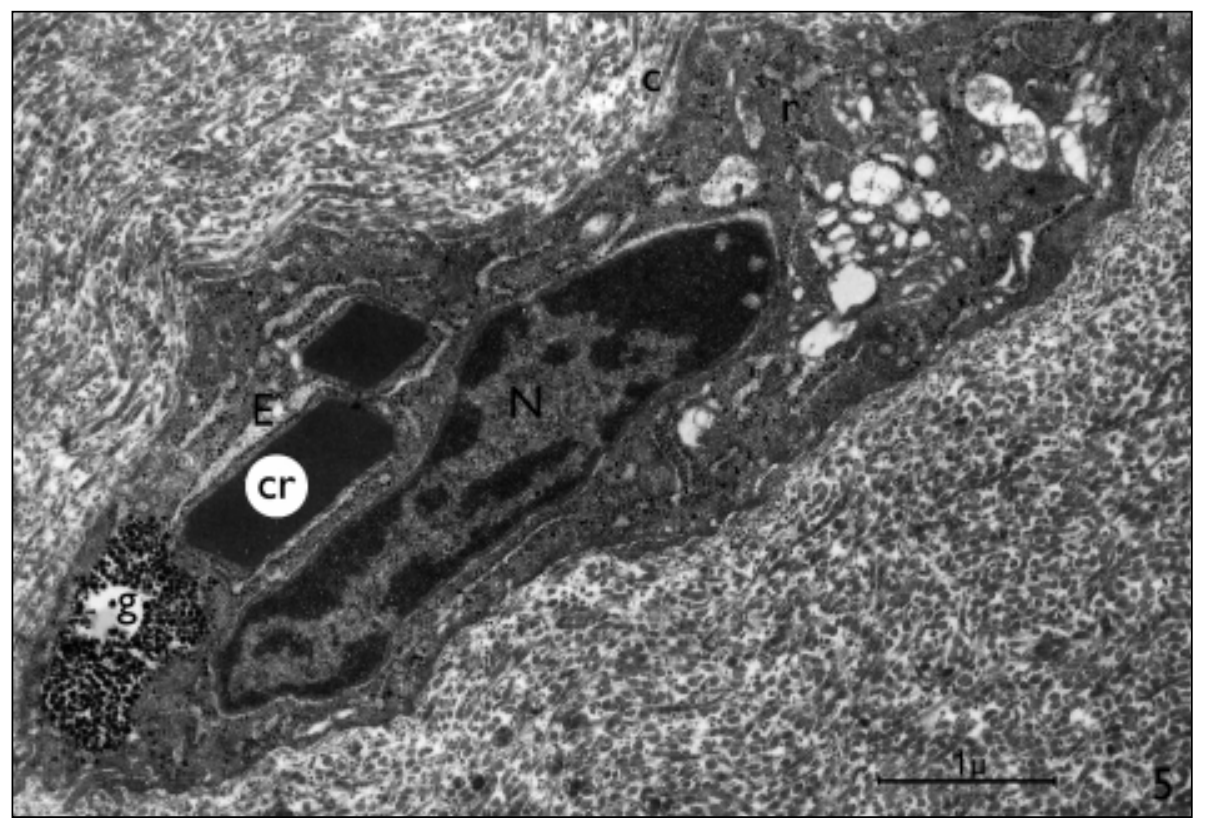

Fig. 5. A chondrocyte (C) with the nucleus (N), dilated GER cisternae (E), glycogen (g), loose ribosomes (r), crystals (cr), collagen fibrils (c). Magnification $\times 16000$.

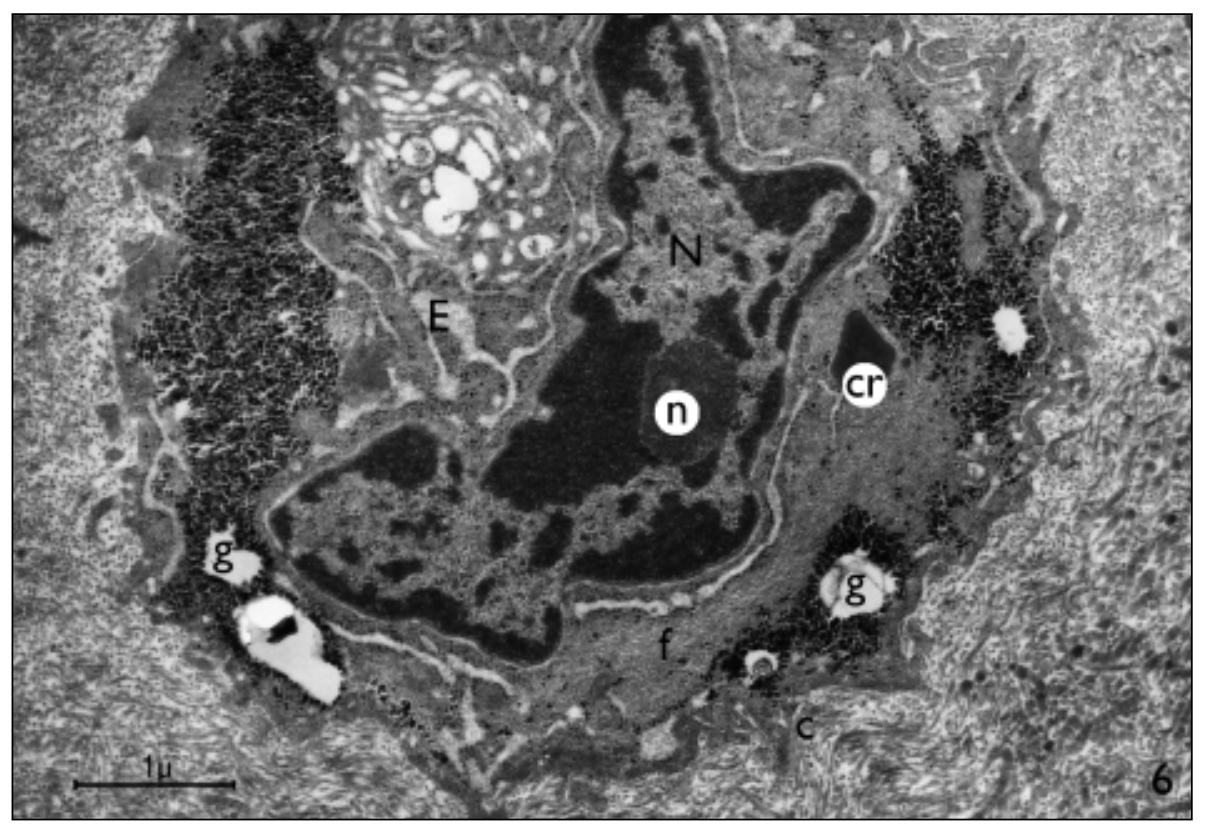

Fig. 6. A chodrocyte in the intermediate layer with the nucleus $(\mathrm{N})$ and nucleolus (n). Dilated GER cisternae (E), bundles of intermediate filaments (f). Glycogen deposits (g), a crystal (cr). Collagen fibrils (c) in the vicinity of the cell membrane. Magnification $\times 17000$. 
Plate IV

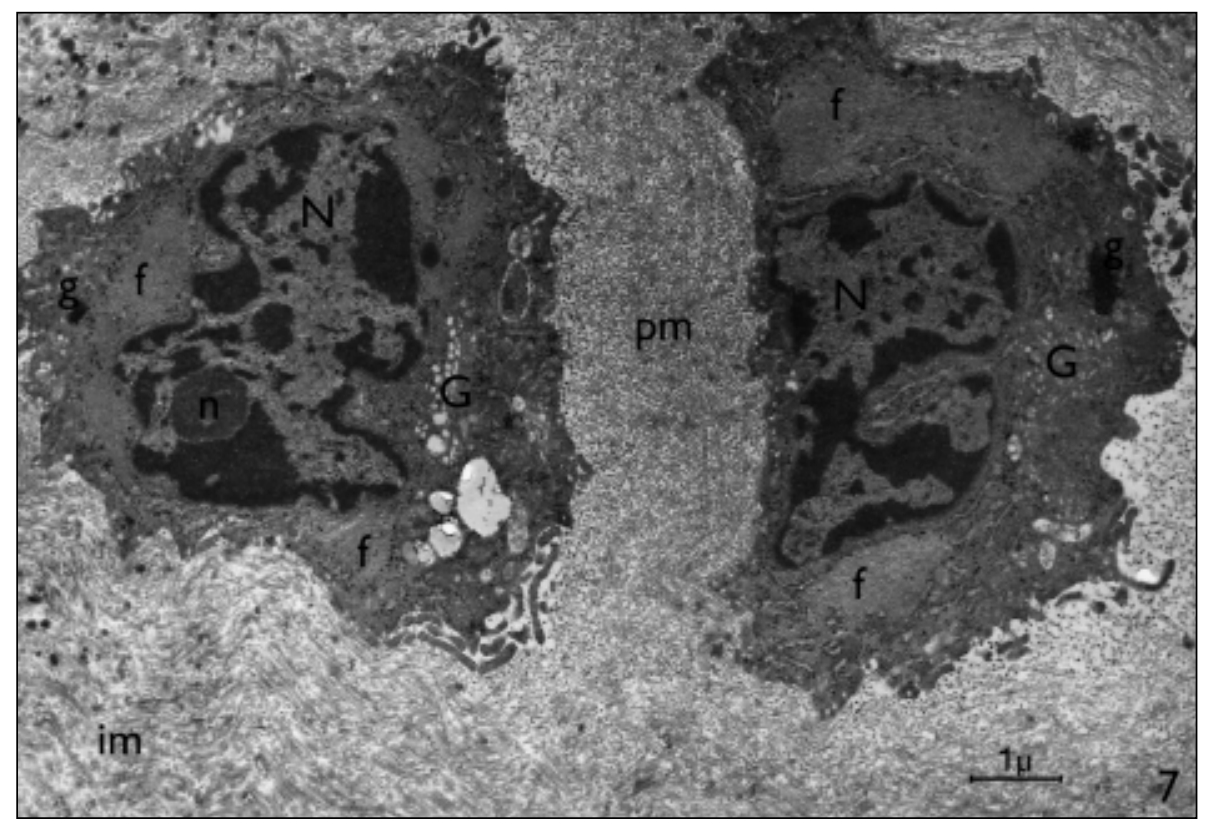

Fig. 7. A pair of chondrocytes in the deep layer. Nucleus (N), nucleolus (n), Golgi complex (G), thick bundles of intermediate filaments (f), glycogen deposits $(\mathrm{g})$. Pericellular $(\mathrm{pm})$ and intercellular (im) matrix. Magnification $\times 12000$.

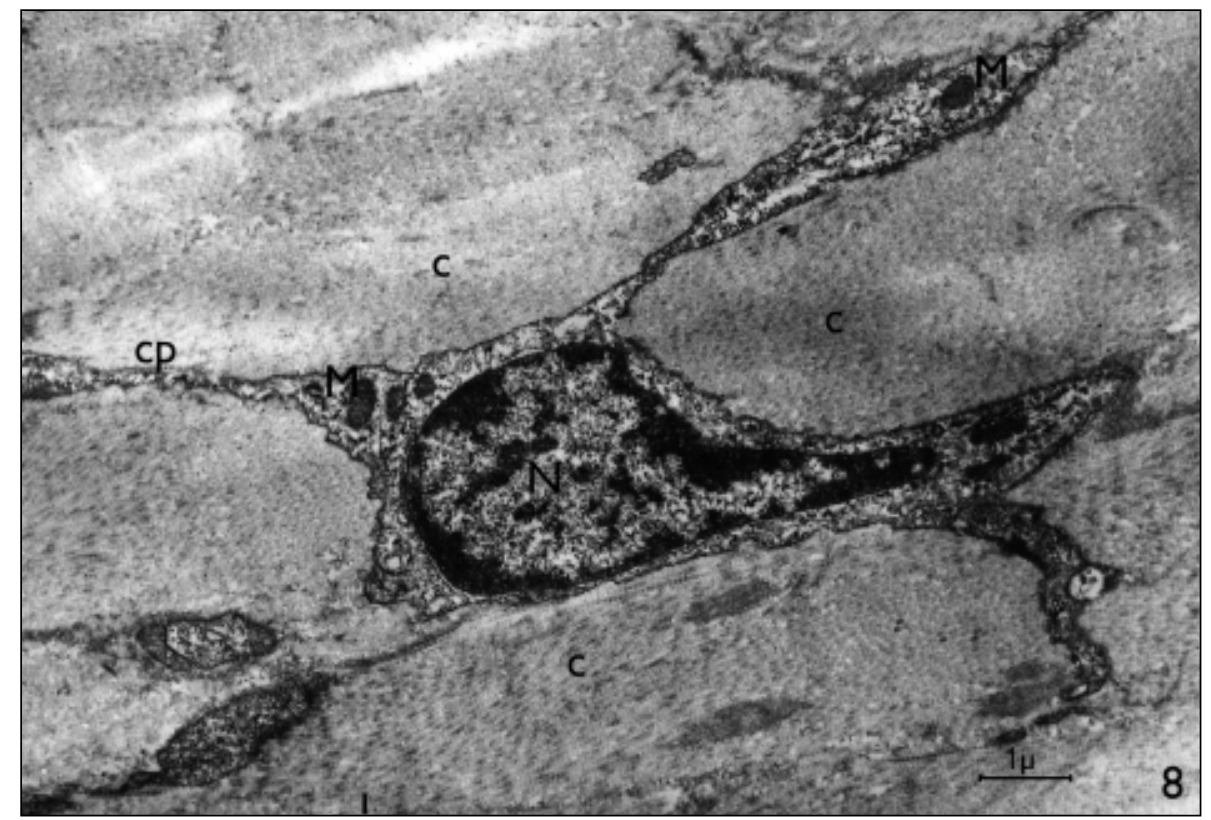

Fig. 8. A fibrocyte from the region close to the tide mark. Nucleus (N), mitochondria (M), long cytoplasmic projections (cp) among bundles of collagen fibrils (c). Magnification $\times 12000$. 